\title{
Occurrence of Entomosporium Leaf Spot on Photinia glabra in Korea
}

\author{
Sang-Tae Seo' ${ }^{1}$ Kyung-Hee Kim ${ }^{1}$, Mi-Jeong Park ${ }^{2}$ and Hyeon-Dong Shin ${ }^{2 *}$ \\ ${ }^{1}$ Division of Forest Diseases and Insect Pests, Korea Forest Research Institute, Seoul 130-712, Korea \\ ${ }^{2}$ Division of Environmental Science and Ecological Engineering, Korea University, Seoul 136-701, Korea \\ (Received on November 30, 2009; Accepted on January 26, 2010)
}

Japanese photinia (Photinia glabra), native to Japan, is an evergreen shrub belonging to the Rosaceae. The plant is widely grown for landscaping and gardening because the bright red foliage has ornamental value. In Korea, it is planted only in southern areas due to its poor winter hardiness. In April 2008, plantings in a nursery in Jeju were severely affected by a leaf spotting and defoliating disease (Fig. 1). The initial symptom of the disease appeared as minute circular spots on either side or on both sides of the leaves. On the young spots, the tan-colored centers with narrow reddish borders were slightly raised. The center of each spot had tiny black specks in which conidia produced by the fungus were found. Several small spots frequently coalesced to make large necrotic blotches in severe infections (Fig. 1C). The continued infection finally led to extensive premature defoliation of the affected trees (Fig. 1A\& B).

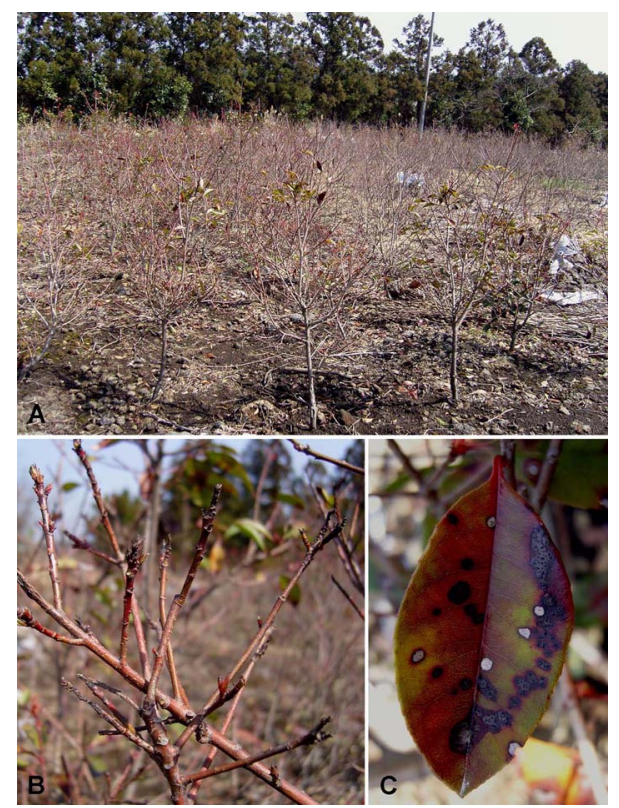

Fig. 1. Typical symptoms on Photinia glabra caused by Entomosporium mespili. (A) Severe premature defoliation in a nursery in Jeju. (B) Branches after premature defoliation. (C) Leaf spots on a diseased leaf.

The leaf spot lesions and the fungus were examined under a microscope. Acervuli were gray to dark grayish, amphigenous but mostly epiphyllous, circular to irregular, produced subepidermally, dehiscent by irregular rupture of the cuticle when mature. Conidia were hyaline, cruciform, 4 to 5-celled, and 22-30 $\times 9-11 \mu \mathrm{m}$. Apical cells were usually slightly larger than basal cells, globose to broadly ellipsoidal, and measured 12-18 $\times 9-11 \mu \mathrm{m}$. Basal cells were globose to subglobose, with a truncate base, and measured 10-12×6-9 $\mu \mathrm{m}$. Lateral cells were 2 to 3 in number, subglobose to broadly cylindric, and measured 6-7×4-5 $\mu \mathrm{m}$. Appendages on apical and each lateral cell were unbranched, tubular, flexuous, attenuated gradually toward the distal end, and 11-20 $\mu \mathrm{m}$ in length (Fig. 2A). Based on these morphological characteristics, the causal fungus of leaf spots on Photinia glabra was identified as Entomosporium mespili (DC.) Sacc. (Nag Raj, 1993).
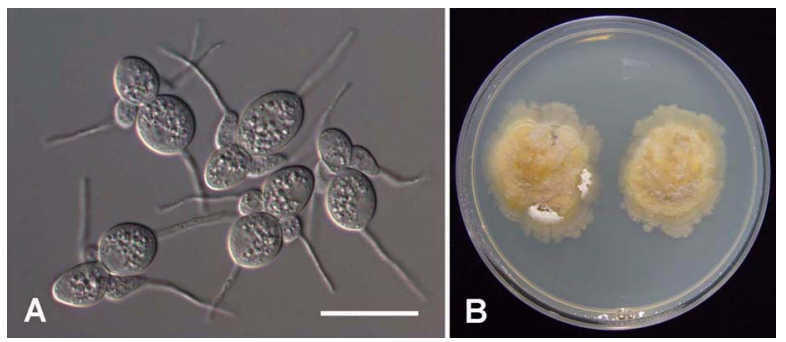

Fig. 2. Photograph of Entomosporium mespili. (A) Conidia. (B) Culture on potato dextrose agar after 6 weeks of incubation. $\mathrm{Bar}=20 \mu \mathrm{m}$.

A monoconidial isolate was cultured on potato dextrose agar(Fig. 2B). The isolate was deposited in the Korean Agricultural Culture Collection (KACC43758). A pathogenicity test was conducted using 2-year-old plants in a greenhouse. Inoculum was prepared by harvesting conidia from the diseased leaves, since the fungus do not readily form conidia on artificial media including PDA. A conidial suspension (ca. $10^{3}$ conidia $/ \mathrm{ml}$ ) was sprayed on ten young leaves wounded with needles. Ten leaves on control trees were sprayed with sterile distilled water. Each plant was covered with a polyethylene bag for the first $48 \mathrm{hr}$ to maintain high moisture. Leaf spot symptoms appeared on the inoculated leaves within 14 days. The fungus was reisolated from those lesions, confirming Koch's postulates. No symptoms developed on control plants.

Entomosporium leaf spot has been known to occur worldwide on rosaceous plants. It has been reported on P. glabra in the USA, New Zealand, and Japan (Farr and Rossman, 2009). To date, in Korea, the leaf spot diseases caused by E. mespili have been recorded on Raphiolepis umbellata (Forestry Research Institute, 1991) and Amelanchier asiatica (Shin et al., 1998). Therefore, this is the first report of E. mespili on P. glabra in Korea. As Japanese photinia become a popular ornamental plant in Korea, this disease has the potential to lead to significant economic losses in nurseries as well as in the landscape.

\section{References}

Farr, D. F. and Rossman, A. Y. 2009. Fungal Databases, Systematic Mycology \& Microbiology Laboratory, ARS, USDA. Retrieved November 24, 2009, from http://nt.ars-grin.gov/fungaldatabases/.

Forestry Research Institute. 1991. Insect Pests and Diseases of Trees and Shrubs. Forestry Administration, Seoul, Korea. 424 pp.

Nag Raj, T. R. 1993. Coelomycetous Anamorphs with Appendage-bearing Conidia. Mycologue Publication, Canada. $1101 \mathrm{pp}$.

Shin, H. D., Lee, H. T., Yang, S. I. and Lee, S. H. 1998. Leaf spot of Amelanchier asiatica caused by Entomosporium mespili. Korean J. Plant Pathol. 14:732-734.

*Corresponding author (hdshin@korea.ac.kr) 